\title{
CORRIGENDA
}

\section{Splanchnic-bed transfers of amino acids in sheep blood and plasma, as monitored through use of a multiple $\mathrm{U}-{ }^{13} \mathrm{C}$-labelled amino acid mixture}

BY G. E. LOBLEY, A. CONNELL, D. K. REVELL, B. J. BEQUETTE, D. S. BROWN AND A. G. CALDER

Vol. 75 (1996), no. 2

Page 221

$\begin{array}{ll}\text { For } & \text { ILR }=\left(\left(0.99 / \mathrm{re}_{b(o r p))}-1\right) \times \mathrm{I},\right. \\ \text { Read } & \text { ILR }=\left(\left(0.99 / \mathrm{re}_{b(o r p)}\right)-1\right) \times \mathrm{I},\end{array}$

And for Conversion of isotope transfers to a corresponding AA flux involves division by an reconsidered representative of the precursor pool for protein synthesis within the tissue.

Read Conversion of isotope transfers to a corresponding AA flux involves division by an re considered representative of the precursor pool for protein synthesis within the tissue. 